\title{
Market Structure AND THE DeMand for Free Trade
}

by

Orlando I. Balboa, Andrew F. Daughety, and Jennifer F. Reinganum

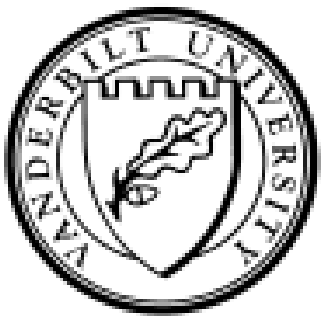

Working Paper No. 01-W12R

July 2001

Revised December 2002

\section{DEPARTMENT OF ECONOMICS \\ VANDERBILT UNIVERSITY \\ NASHVILLE, TN 37235}

www.vanderbilt.edu/econ 
Market Structure and the Demand for Free Trade*

Orlando I. Balboa**
Andrew F. Daughety**
Jennifer F. Reinganum**

July 2001

Revised: December 2002

* We thank James Brander, Robert Driskill, Nolan Miller, Barbara Spencer, Kathryn Spier, two referees and the co-editor for their comments on earlier versions.

** Department of Economics, Vanderbilt University, Nashville, TN 37235 
Market Structure and the Demand for Free Trade

Orlando I. Balboa

Andrew F. Daughety

Jennifer F. Reinganum

\begin{abstract}
We explore the interplay of market structure and government trade policy in the context of a heterogenous goods duopoly model (allowing for goods to be substitutes or complements) wherein governments simultaneously and noncooperatively choose whether or not to provide subsidies for their firms and then firms noncooperatively choose output levels, either sequentially (i.e., in a Stackelberg leader-follower model) or simultaneously (i.e., in a Cournot-Nash model). We focus on competition in quantities but also provide results when firms compete in prices. In both the quantity and price models we further allow for endogenous market structure by considering the case wherein one of the firms, a potential leader, can choose to lead or not lead (play Cournot).

We find that government trade policy and market structure can interact. First, the trade regime can alter traditional firm preferences over sequential versus simultaneous play. Second, different market structures can influence governments' preferences about free trade versus subsidies. Further, if one of the firms is a potential leader, allowing for endogenous market structure generates equilibrium outcomes that sometimes reinforce, and sometimes counter, received results in the extant strategic trade literature. For example, when firms compete in quantities, endogenous market structure results in Cournot-Nash competition. On the other hand, competition in prices results in a leader-follower structure when the goods are substitutes, but a Cournot-Nash structure when the goods are complements.
\end{abstract}


1. Introduction

Much of the extant literature on strategic international trade takes market structure as given, but it would not be surprising that government trade policies might influence the market structure that arises in equilibrium, ${ }^{1}$ nor might it be surprising that different market structures may influence the efficacy of alternative government trade policies. Thus, in this paper we re-examine some issues in industrial organization and strategic international trade that were first addressed in the mid-1980s and stimulated the development of extensive related literatures. The relevant industrial organization literature focused on firms' preferences over sequential versus simultaneous play in markets (see, e.g., Gal-Or, 1985 and Dowrick, 1986). ${ }^{2}$ This literature generally ignores the role of governments and thus no consideration of taxes or subsidies is involved. In contrast, the relevant strategic international trade literature focused on a two-stage model in which governments first chose tax or subsidy rates and subsequently their domestic firms simultaneously chose output or price strategies in a third-country market (see, e.g., Brander and Spencer, 1985, and Grossman and Eaton, 1986, respectively), in part in order to determine circumstances under which governments would prefer free trade. Since these seminal papers were written, many variations have been considered. ${ }^{3}$

${ }^{1}$ For example, Harris (1985) and Krishna (1989) show that the imposition of a voluntary export restraint on a foreign firm converts the domestic firm into a price leader.

2 A variety of endogenous timing models have been devised to rationalize asymmetry in behavior as an equilibrium outcome (see, for example, Boyer and Moreaux, 1987; Gal-Or, 1987; Sadanand, 1988; Hamilton and Slutsky, 1990; Robson, 1990; Mailath, 1993; Daughety and Reinganum, 1994; Maggi, 1996a; Sadanand and Sadanand, 1996; Amir and Grilo, 1999; and van Damme and Hurkens, 1999).

3 See Brander (1995) for a recent survey. For instance, papers addressing variations in the timing of moves include Carmichael (1987) and Gruenspecht (1988), in which the firms move before the governments; and Arvan (1991) and Hwang and Schulman (1993), in which the governments may move sequentially, but the firms are Cournot-Nash players. Dixit (1984) varies the number of firms, and places the competing firms in a "reciprocal-markets" context (as opposed 
However, to our knowledge, no one has yet considered the case wherein the two governments first choose tax or subsidy rates and subsequently their domestic firms sequentially choose their strategies. We argue that sequential play is a plausible outcome and we demonstrate how the possibility of sequential timing of firms' decisions impacts both the industrial organization results on role preferences and the strategic international trade results on governments' preferences for free trade. ${ }^{4}$

Thus, we consider leader/follower market structures as well as more traditional simultaneous-move market structures. One way to commit to the leadership role is by making a strategic investment that will induce the rival firm to prefer the follower role. While some of the previously mentioned models focus on capacity choice, other strategic investments can provide sequential-move market structures as well. For instance, Daughety and Reinganum (1994) provide a model of endogenous information acquisition and endogenously-determined timing of production. In a subgame wherein one firm has private information (say, about demand or cost) and there is a commitment-based advantage to moving first, then there is an information-based advantage to moving second: a follower can infer the leader's private information from the leader's behavior and take it into account in making his own strategy choice, without direct expenditure for the information itself. Moreover, when information acquisition is endogenous but costly, we showed that firms that are ex ante identical will end up choosing asymmetrically: one firm will pay the cost

to the "third-market" context). Driskill and McCafferty (1989) provide a dynamic version of Eaton and Grossman's model.

${ }^{4}$ Although recent trade agreements (e.g., GATT, WTO) strive to eliminate government trade interventions, a production tax or subsidy is a feasible alternative, and these are currently in use in a variety of industries. Moreover, these agreements are not necessarily stable and an analysis of the hypothetical use of trade policies can shed light on potential sources of instability. 
to become informed and will then adopt the leader role; the other firm will adopt the follower role and become informed by monitoring the behavior of the leader. Thus, a means for a potential leader to commit to a leadership role, without restricting decisions to be made later about quantity or price, is to invest in a "marketing department" which observes (random) demand every period; the other firm would (optimally) adopt the follower role and learn whether demand is high or low by observing the informed leader. Alternatively, if the technology is subject to random improvement, then the potential leader could invest in an "R\&D lab" which generates innovations; the other firm would (optimally) adopt the follower role and imitate any technological improvements. To keep the analysis tractable, and to maintain comparability with the industrial organization and international trade literatures discussed above, we do not formally embed such a complex market subgame in our multistage model; rather, we employ the familiar complete-information Cournot and Stackelberg market subgames in our analysis.

Assuming that the firms compete in quantity strategies, we find that, in a regime of subsidies, firms' preferences over roles are completely reversed from their preferences under free trade (those found in the industrial organization literature) when the goods are substitutes. When the goods are complements, the reversals are partial, and they differ for firms and their respective governments. We also find that firms' and their governments' preferences over trade regime can, but need not, be affected by the timing of output choice in the market. In particular, when the goods are complements, both firms and both governments prefer a regime of subsidies independent of the timing of output choice. The case of substitute goods is more complicated: when the market involves simultaneous moves, firms prefer a regime of subsidies while their governments prefer free trade. However, free trade is not a Nash equilibrium for the governments; subsidization is a 
dominant strategy for each government. This is the familiar "prisoners' dilemma" outcome, which the governments can remedy by using trigger strategies in repeated interactions to support the free trade outcome. By contrast, we find that when the market involves sequential moves, the leader firm and its government prefer free trade while the follower firm and its government prefer a regime of subsidies. Thus, the governments disagree about the desirability of free trade. Moreover, it is a dominant strategy for the leader firm's government to neither tax nor subsidize its domestic firm, so there is no credible punishment strategy to which this government can revert in order to support its desired outcome of free trade. Thus, reliance on repeated game arguments to achieve free trade are not robust to variations in market structure. One further implication of this is that a government whose domestic firms are often Stackelberg leaders in markets will extol the virtues of free trade to its domestic firms (i.e., refuse to subsidize them), while exerting little effort to prevent the foreign government from subsidizing its firm (in the case of complements) or exerting effort but having little success (in the case of substitutes). In order to sustain a free trade outcome in the case of substitutes, the governments might make trade agreements that involve multiple markets, but this would require that (1) a government whose firm is a follower in some markets is also a leader in other markets; and (2) the gains from free trade in those markets in which each firm is a leader must offset the losses from free trade in those markets in which each firm is a follower.

We take the analysis further, allowing for the market structure itself to be endogenously determined. Thus, the presence of alternative government strategies with respect to trade turns out to influence the market structure in which the firms will compete. In particular, if a firm that is able to exert a leadership position can choose not to assume that role (that is, it can choose to "play Cournot" instead), then the resulting market structure is Cournot-Nash, not Stackelberg. Thus, the 
early results in the trade literature, which assumed quantity competition in a Cournot-Nash market structure, turn out to be robust. This fails to be true if firms compete in prices rather than in quantities and the goods are substitutes (see Section 8); now sequentiality becomes the robust outcome.

There are two more strands of the IO literature which are related to this paper. First, there is a small literature on the choice of strategy space (see Singh and Vives, 1984; Klemperer and Meyer, 1986; and Maggi, 1996b). We will assume the strategy space is fixed (e.g., by technology or tradition), but this is clearly a possible direction of extension. Second, strategic trade models are multi-stage games, usually with the governments playing first and the firms playing second (engaging in market competition). In a related literature from IO (called the "delegation" literature), owners move first, followed by managers moving second. Owners design incentive contracts under which their respective managers subsequently compete in the market (see, e.g., Vickers, 1984; Fershtman and Judd, 1987; and Sklivas, 1987). ${ }^{5}$ As has been true of the strategic trade literature, the nature of the incentive contract changes as a function of the strategy space used by the managers. There has been a partial convergence of these two literatures. In a recent paper, Miller and Pazgal (2001) show that, if the owners can employ sufficiently general incentive schemes, then the equilibrium market outcome will be independent of the strategy space in which the managers compete (i.e., they can both choose prices, or both choose quantities, or one can

${ }^{5}$ Since completing this paper, we have discovered Lambertini (2000), which examines the delegation problem assuming that firms may play sequentially in the market subgame. In addition to the difference in application (strategic trade versus delegation) we consider both complements and substitutes, and we address the question of whether the countries can (or want to) use trigger strategies to support free trade, incorporating the potential leader's decision to accept or decline its option to lead. 
choose price while the other chooses quantity). For the case of linear demand and constant marginal costs, a linear combination of own profits and rival profits is sufficient to obtain this independence result. However, they also show that a linear combination of own profits and own output is not sufficient for this equivalence result to hold. The implication for the strategic trade literature is that the strategy space will continue to be important because the objective function for the firm is of the second form, since it consists of own profits plus the subsidy rate times own output. Considering government policies that incorporate own and foreign profits and outputs may be a source of yet further extension, but this is beyond the scope of the current paper.

\section{$\underline{\text { Plan of the Paper }}$}

In Section 2, we define notation and describe the model to be used in the remainder of the paper. In Sections 3 and 4, we reiterate the findings from the industrial organization literature on firms' preferences over roles, and from the strategic trade literature on firms' and governments' preferences over the trade regime, respectively. In Section 5, we solve the game wherein the governments first choose subsidy rates simultaneously and noncooperatively, and the firms then compete through a sequential choice of output levels. In Section 6 we compare these results with those of Sections 3 and 4, emphasizing the impact of trade regime on role preferences and the impact of market structure on preferences over trade regimes. In Section 7, we re-examine these issues under the assumption that a potential leader firm can choose to lead or to play Cournot-Nash (i.e., a firm with the opportunity to move first can choose to defer its choice and move simultaneously). Section 8 reports results comparable to those of Section 6 assuming the firms use price strategies and again considers the endogenous determination of market structure. Finally, Section 9 summarizes and concludes. Tables containing intermediate results are contained in the Appendix; 
a "Web Appendix" contains the proofs of the propositions (this is available from the authors, or at http://www.vanderbilt.edu/Econ/faculty/Daughety/Daughetyhome.html).

\section{The Model: Quantity Strategies}

In this section, we describe the basic notation and common elements of the models to be examined in the remainder of the paper. We assume that two firms, each located in a different country, compete in a market which operates in a third country. For simplicity, we will confine ourselves to the case of linear demand and constant marginal costs. Many of the received results hold under more general conditions; as we reach them, we will specifically note two of our key results (concerning incentives for the governments of firms that move sequentially) that hold more generally.

Let $\mathrm{p}_{\mathrm{i}}\left(\mathrm{q}_{1}, \mathrm{q}_{2}\right)=\mathrm{a}-\mathrm{bq}_{\mathrm{i}}-\mathrm{dq}_{\mathrm{j}}$ represent the inverse demand function for good $\mathrm{i}$, which is produced only by firm $\mathrm{i}$, which is located in country $\mathrm{i}, \mathrm{i}=1,2$. The goods are sold in a market in a third country. The parameter $b>0$ represents the effect of an increase in firm i's own output on firm i's inverse demand and the parameter $d$ represents the effect of an increase in the rival firm's output on firm i's inverse demand. If $d>0$, the goods are substitutes, while if $d<0$ the goods are complements (if $d=0$, the goods are independent). These demand functions are derived from a quadratic utility model which requires that $|\mathrm{d}|<\mathrm{b}$, so we impose this parameter restriction throughout. Let $\mathrm{C}_{\mathrm{i}}\left(\mathrm{q}_{\mathrm{i}}\right)=\mathrm{cq}_{\mathrm{i}}$, where $\mathrm{a}>\mathrm{c}>0$ is a constant (c reflects per unit production and transportation costs). Finally, let $\mathrm{s}_{\mathrm{i}}$ denote a per unit subsidy (where $\mathrm{s}_{\mathrm{i}}<0$ is actually a per unit tax) applied to the output of firm i by the government of country $i$ (also known as government i).

We denote firm i's profits by $\pi_{\mathrm{i}}\left(\mathrm{q}_{1}, \mathrm{q}_{2}, \mathrm{~s}_{\mathrm{i}}\right)=\mathrm{p}_{\mathrm{i}}\left(\mathrm{q}_{1}, \mathrm{q}_{2}\right) \mathrm{q}_{\mathrm{i}}-\mathrm{cq}_{\mathrm{i}}+\mathrm{s}_{\mathrm{i}} \mathrm{q}_{\mathrm{i}}$; the firms' equilibrium 
output levels will depend upon the subsidy rates $\left(\mathrm{s}_{1}, \mathrm{~s}_{2}\right)$. We will consider both a simultaneous-move and a sequential-move market structure. Let $\mathrm{q}_{\mathrm{i}}{ }^{\mathrm{CN}}\left(\mathrm{s}_{1}, \mathrm{~s}_{2}\right)$ denote firm i's (Cournot-Nash) equilibrium output level when the market structure involves the firms choosing their output levels noncooperatively and simultaneously. Let $\mathrm{q}_{\mathrm{i}}{ }^{\mathrm{L}}\left(\mathrm{s}_{1}, \mathrm{~s}_{2}\right)$ denote firm i's equilibrium output level when the market structure involves firm i moving first (as a Stackelberg leader) and firm $\mathrm{j}$ moving second (as a Stackelberg follower). Finally, let $\mathrm{q}_{\mathrm{i}}^{\mathrm{F}}\left(\mathrm{s}_{1}, \mathrm{~s}_{2}\right)$ denote firm i's equilibrium output level when the market structure involves firm $\mathrm{j}$ moving first (as a Stackelberg leader) and firm i moving second (as a Stackelberg follower). Let $\pi_{\mathrm{i}}{ }^{\mathrm{CN}}\left(\mathrm{s}_{1}, \mathrm{~s}_{2}\right)=\pi_{\mathrm{i}}\left(\mathrm{q}_{1}{ }^{\mathrm{CN}}\left(\mathrm{s}_{1}, \mathrm{~s}_{2}\right), \mathrm{q}_{2}{ }^{\mathrm{CN}}\left(\mathrm{s}_{1}, \mathrm{~s}_{2}\right), \mathrm{s}_{\mathrm{i}}\right)$ denote firm $\mathrm{i}$ 's profits in the simultaneous-move market. Without loss of generality and for ease of discussion, in the leaderfollower setting we will designate firm 1 as the leader. Let $\pi_{1}{ }^{\mathrm{L}}\left(\mathrm{s}_{1}, \mathrm{~s}_{2}\right)=\pi_{1}\left(\mathrm{q}_{1}{ }^{\mathrm{L}}\left(\mathrm{s}_{1}, \mathrm{~s}_{2}\right), \mathrm{q}_{2}{ }^{\mathrm{F}}\left(\mathrm{s}_{1}, \mathrm{~s}_{2}\right), \mathrm{s}_{1}\right)$ denote firm 1's profits in the sequential-move market wherein firm 1 is the leader and, similarly, let $\pi_{2}{ }^{\mathrm{F}}\left(\mathrm{s}_{1}, \mathrm{~s}_{2}\right)=\pi_{2}\left(\mathrm{q}_{1}{ }^{\mathrm{L}}\left(\mathrm{s}_{1}, \mathrm{~s}_{2}\right), \mathrm{q}_{2}{ }^{\mathrm{F}}\left(\mathrm{s}_{1}, \mathrm{~s}_{2}\right), \mathrm{s}_{2}\right)$ denote firm 2's profits in the sequential-move market wherein firm 2 is the follower.

We assume that government i's payoff function, denoted $\mathrm{w}_{\mathrm{i}}$, consists of domestic profits minus subsidies paid. Since the firms' equilibrium output levels will be functions of the subsidy rates, we will write $\mathrm{w}_{\mathrm{i}}$ as a function of $\mathrm{s}_{1}$ and $\mathrm{s}_{2}$. Thus, $\mathrm{w}_{\mathrm{i}}{ }^{\mathrm{CN}}\left(\mathrm{s}_{1}, \mathrm{~s}_{2}\right)=\pi_{\mathrm{i}}{ }^{\mathrm{CN}}\left(\mathrm{q}_{1}{ }^{\mathrm{CN}}\left(\mathrm{s}_{1}, \mathrm{~s}_{2}\right), \mathrm{q}_{2}{ }^{\mathrm{CN}}\left(\mathrm{s}_{1}, \mathrm{~s}_{2}\right), \mathrm{s}_{\mathrm{i}}\right)$ $\mathrm{s}_{\mathrm{i}} \mathrm{q}_{\mathrm{i}}{ }^{\mathrm{CN}}\left(\mathrm{s}_{1}, \mathrm{~s}_{2}\right)$ denotes government $\mathrm{i}$ 's payoff when the firms choose their output levels simultaneously. Similarly, $\mathrm{w}_{1}{ }^{\mathrm{L}}\left(\mathrm{s}_{1}, \mathrm{~s}_{2}\right)=\pi_{1}{ }^{\mathrm{L}}\left(\mathrm{q}_{1}{ }^{\mathrm{L}}\left(\mathrm{s}_{1}, \mathrm{~s}_{2}\right), \mathrm{q}_{2}{ }^{\mathrm{F}}\left(\mathrm{s}_{1}, \mathrm{~s}_{2}\right), \mathrm{s}_{1}\right)-\mathrm{s}_{1} \mathrm{q}_{1}{ }^{\mathrm{L}}\left(\mathrm{s}_{1}, \mathrm{~s}_{2}\right)$ denotes government 1's payoff in the sequential-move game wherein firm 1 is the leader and firm 2 is the follower, and $\mathrm{w}_{2}{ }^{\mathrm{F}}\left(\mathrm{s}_{1}, \mathrm{~s}_{2}\right)=$ $\pi_{2}{ }^{\mathrm{F}}\left(\mathrm{q}_{1}{ }^{\mathrm{L}}\left(\mathrm{s}_{1}, \mathrm{~s}_{2}\right), \mathrm{q}_{2}{ }^{\mathrm{F}}\left(\mathrm{s}_{1}, \mathrm{~s}_{2}\right), \mathrm{s}_{2}\right)-\mathrm{s}_{2} \mathrm{q}_{2}{ }^{\mathrm{F}}\left(\mathrm{s}_{1}, \mathrm{~s}_{2}\right)$ denotes government 2's payoff in the sequential-move game wherein firm 1 is the leader and firm 2 is the follower. Throughout the paper, we will assume that the governments move simultaneously; only the timing of firms' output decisions will be varied. 
Let $\mathrm{s}_{\mathrm{i}}{ }^{\mathrm{CN}}$ denote government $\mathrm{i}$ 's Nash equilibrium subsidy rate when the firms choose output levels simultaneously. Similarly, let $\mathrm{s}_{1}{ }^{\mathrm{L}}$ and $\mathrm{s}_{2}{ }^{\mathrm{F}}$ denote the respective governments' Nash equilibrium subsidy rates when firm 1 is a Stackelberg leader and firm 2 is a Stackelberg follower in the output market.

Finally, we will distinguish the ultimate equilibrium quantities and payoffs of the firms and their governments by using upper case letters to signify the equilibrium outcome under free trade, and lower case letters to signify the equilibrium outcome in the subsidy regime. Since the firms and their governments are symmetric, except possibly for firm roles, we can suppress the subscript $i$ on the equilibrium quantities and payoffs. Thus, $\mathrm{Q}^{\mathrm{CN} *}=\mathrm{q}_{\mathrm{i}}^{\mathrm{CN}}(0,0)$ is a firm's equilibrium quantity under free trade, while $\mathrm{q}^{\mathrm{CN} *}=\mathrm{q}_{\mathrm{i}}{ }^{\mathrm{CN}}\left(\mathrm{s}_{1}{ }^{\mathrm{CN}}, \mathrm{s}_{2}{ }^{\mathrm{CN}}\right)$ is a firm's equilibrium output in the subsidy regime, when the firms choose output simultaneously. Likewise, $\mathrm{Q}^{\mathrm{L} *}=\mathrm{q}_{1}{ }^{\mathrm{L}}(0,0)$ is the Stackelberg leader's equilibrium quantity under free trade, while $\mathrm{q}^{\mathrm{L} *}=\mathrm{q}_{1}{ }^{\mathrm{L}}\left(\mathrm{s}_{1}{ }^{\mathrm{L}}, \mathrm{s}_{2}{ }^{\mathrm{F}}\right)$ is the Stackelberg leader's equilibrium quantity in the subsidy regime. Further, $\mathrm{Q}^{\mathrm{F} *}=\mathrm{q}_{2}{ }^{\mathrm{F}}(0,0)$ is the Stackelberg follower's equilibrium quantity under free trade, while $\mathrm{q}^{\mathrm{F} *}=\mathrm{q}_{2}{ }^{\mathrm{F}}\left(\mathrm{s}_{1}{ }^{\mathrm{L}}, \mathrm{s}_{2}{ }^{\mathrm{F}}\right)$ is the Stackelberg follower's equilibrium quantity in the subsidy regime. The analogous notation for equilibrium profits is: $\Pi^{\mathrm{CN} *}=\pi_{\mathrm{i}}^{\mathrm{CN}}(0,0)$ and $\pi^{\mathrm{CN} *}=\pi_{\mathrm{i}}^{\mathrm{CN}}\left(\mathrm{s}_{1}{ }^{\mathrm{CN}}, \mathrm{s}_{2}{ }^{\mathrm{CN}}\right)$ when the firms choose output simultaneously; and $\Pi^{\mathrm{L} *}=\pi_{1}{ }^{\mathrm{L}}(0,0), \pi^{\mathrm{L} *}=$ $\pi_{1}{ }^{\mathrm{L}}\left(\mathrm{s}_{1}{ }^{\mathrm{L}}, \mathrm{s}_{2}{ }^{\mathrm{F}}\right), \Pi^{\mathrm{F} *}=\pi_{2}{ }^{\mathrm{F}}(0,0)$ and $\pi^{\mathrm{F} *}=\pi_{2}{ }^{\mathrm{F}}\left(\mathrm{s}_{1}{ }^{\mathrm{L}}, \mathrm{s}_{2}{ }^{\mathrm{F}}\right)$ when the firms move sequentially. Similarly, the analogous notation for equilibrium government payoffs is: $\mathrm{W}^{\mathrm{CN} *}=\mathrm{w}_{\mathrm{i}}{ }^{\mathrm{CN}}(0,0)$ and $\mathrm{w}^{\mathrm{CN} *}=$ $\mathrm{W}_{\mathrm{i}}{ }^{\mathrm{CN}}\left(\mathrm{s}_{1}{ }^{\mathrm{CN}}, \mathrm{s}_{2}{ }^{\mathrm{CN}}\right)$ when the firms choose output simultaneously; and $\mathrm{W}^{\mathrm{L} *}=\mathrm{w}_{1}{ }^{\mathrm{L}}(0,0), \mathrm{w}^{\mathrm{L} *}=$ $\mathrm{w}_{1}{ }^{\mathrm{L}}\left(\mathrm{s}_{1}{ }^{\mathrm{L}}, \mathrm{s}_{2}{ }^{\mathrm{F}}\right), \mathrm{W}^{\mathrm{F} *}=\mathrm{w}_{2}{ }^{\mathrm{F}}(0,0)$ and $\mathrm{w}^{\mathrm{F} *}=\mathrm{w}_{2}{ }^{\mathrm{F}}\left(\mathrm{s}_{1}{ }^{\mathrm{L}}, \mathrm{s}_{2}{ }^{\mathrm{F}}\right)$ when the firms move sequentially. 
3. Solution of the Simultaneous-Move and Sequential-Move Market Games under Free Trade We briefly present the solution of the Cournot-Nash and Stackelberg games under free trade in order to illustrate the industrial organization issue: what is a firm's preference ordering over the roles of Stackelberg leader, Cournot-Nash player and Stackelberg follower? Since this issue was addressed in the industrial organization context, the potential impact of government subsidy policy was not incorporated. Key papers in this area include Gal-Or (1985) and Dowrick (1986). Gal-Or found that Stackelberg leadership was advantageous when the two firms' strategies were strategic substitutes $^{6}$ and hence best-response functions sloped downward. On the other hand, Stackelberg leadership was disadvantageous when firms' strategies were strategic complements and hence bestresponse functions sloped upward. For example, when firms choose quantity strategies and the goods themselves are substitutes, this is a case of strategic substitutes; if we change one aspect alone (e.g., quantity strategies with complementary goods, or price strategies with substitute goods), then this becomes a case of strategic complements. Dowrick extended the preference ordering to include Cournot-Nash play, and found that firms' preference orderings were as follows (restricting consideration to the case wherein firms produce goods that are substitutes): when the firms' strategies were strategic substitutes, then Stackelberg leadership was preferred to Cournot-Nash play, which was preferred to Stackelberg followership. On the other hand, when the firms' strategies were strategic complements, then Stackelberg followership was preferred to Stackelberg leadership, which was preferred to Cournot-Nash play. In this latter case, both firms agree that sequential play is preferred to simultaneous play, but they disagree over roles.

Given the basic model and notation described in Section 2, it is straightforward to verify that

${ }^{6}$ That is, $\partial\left[\partial \pi_{\mathrm{i}}\left(\mathrm{q}_{1}, \mathrm{q}_{2}, \mathrm{~s}_{\mathrm{i}}\right) / \partial \mathrm{q}_{\mathrm{i}}\right] / \partial \mathrm{q}_{\mathrm{j}}<0, \mathrm{j} \neq \mathrm{i}$; strategic complements reverses the inequality. 
these relationships hold for our model with quantity strategies, and we present the results here only for purposes of comparison with what is to come; the model and results are well-known in industrial organization.

First consider the simultaneous-move market game; since we are considering the free trade regime, we set $s_{1}=s_{2}=0$. Profits for firm $i$ are given by $\pi_{i}\left(q_{1}, q_{2}, 0\right)=\left(a-b q_{i}-d q_{j}\right) q_{i}-c q_{i}, i=1,2$. Firm i's best response function is given by $\mathrm{BR}_{\mathrm{i}}\left(\mathrm{q}_{\mathrm{j}}, 0\right)=\left(\mathrm{a}-\mathrm{c}-\mathrm{dq}_{\mathrm{j}}\right) / 2 \mathrm{~b}, \mathrm{i}=1,2$, which is downwardsloping if and only if $d>0$ (the goods are substitutes). Note that $\partial\left[\partial \pi_{i}\left(q_{1}, q_{2}, 0\right) / \partial q_{i}\right] / \partial q_{j}=-d$, so that strategies are strategic substitutes if and only if the goods are substitutes. Table A1 in the Appendix provides a summary of the Cournot-Nash equilibrium output levels, profits and governmental payoffs. Under free trade, there are no subsidies or taxes, so government i's payoff is the same as firm i's profit.

Now consider the sequential-move market game in which firm 1 is arbitrarily designated the Stackelberg leader. Profits for firm 2 (the Stackelberg follower) are given by $\pi_{2}\left(q_{1}, q_{2}, 0\right)=\left(a-b q_{2}\right.$ $\left.-\mathrm{dq}_{1}\right) \mathrm{q}_{2}-\mathrm{cq}_{2}$. As before, firm 2's best response function is given by $\mathrm{BR}_{2}\left(\mathrm{q}_{2}, 0\right)=\left(\mathrm{a}-\mathrm{c}-\mathrm{dq}_{1}\right) / 2 \mathrm{~b}$. Thus, $\left.\pi_{1}\left(\mathrm{q}_{1}, \mathrm{BR}_{2}\left(\mathrm{q}_{1}, 0\right), 0\right)=\left(\mathrm{a}-\mathrm{bq}_{1}-\mathrm{d}\left(\mathrm{a}-\mathrm{c}-\mathrm{dq}_{1}\right) / 2 \mathrm{~b}\right)\right) \mathrm{q}_{1}-\mathrm{cq}_{1}$. Table A2 in the Appendix provides the Stackelberg equilibrium output levels, profits and governmental payoffs under free trade when firm 1 is the leader and firm 2 is the follower. Again, under free trade, payoffs to a government and its firm are the same.

It is now straightforward to verify that:

(1) for the case of strategic substitutes, $\Pi^{\mathrm{L} *}>\Pi^{\mathrm{CN} *}>\Pi^{\mathrm{F} *}$ (that is, a firm would prefer being a Stackelberg leader to being a Cournot-Nash player, which is preferred to being a Stackelberg follower); and 
(2) for the case of strategic complements, $\Pi^{\mathrm{F} *}>\Pi^{\mathrm{L} *}>\Pi^{\mathrm{CN} *}$ (that is, a firm would prefer being a Stackelberg follower to being a leader, which is preferred to being a Cournot-Nash player).

Keep in mind that since this is a game in quantity strategies with linear demand and constant marginal costs, this translates into a relationship between the nature of the good itself and the preference ordering: (1) if goods are substitutes then $\Pi^{\mathrm{L} *}>\Pi^{\mathrm{CN} *}>\Pi^{\mathrm{F} *}$; (2) if goods are complements then $\Pi^{\mathrm{F} *}>\Pi^{\mathrm{L} *}>\Pi^{\mathrm{CN} *}$.

\section{Solution of the Subsidy Regime Game under Simultaneous-Move Markets}

In this section, we briefly present the solution of our model when governments simultaneously choose subsidy rates and subsequently their respective domestic firms simultaneously choose quantity strategies; thus, this section includes the standard results initially developed and explored by Brander and Spencer (1985). Market competition is assumed, for simplicity, to occur in a third country, so the governments' objective functions can be identified with domestic firm profits minus the amount of subsidies paid. Brander and Spencer (1985) considered the case of substitute goods and found that equilibrium trade policy employed subsidies, not taxes. Moreover, they showed that while unilateral subsidy was advantageous to a government, when both governments engaged in subsidy policies, both governments were ultimately worse off. That is, while both governments preferred the free trade outcome to the bilateral subsidy outcome, subsidizing one's domestic firm was a dominant strategy. This prisoners' dilemma could be resolved by using trigger strategies in which each government would abstain from subsidizing its domestic firm as long as the other government adhered to this same policy; however, any defection 
from free trade would be met with retaliatory defection, resulting in the bilateral subsidy outcome in the future. Again, given the basic model and notation described in Section 2, it is straightforward to verify that these results also hold for our model with quantity strategies and substitute goods, and we present the results here only for purposes of comparison with what is to come; the model and results are well-known in the strategic international trade area.

First consider the simultaneous-move market game, with arbitrary subsidy rates $\left(\mathrm{s}_{1}, \mathrm{~s}_{2}\right)$. Profits for firm $\mathrm{i}$ are given by $\pi_{\mathrm{i}}\left(\mathrm{q}_{1}, \mathrm{q}_{2}, \mathrm{~s}_{\mathrm{i}}\right)=\left(\mathrm{a}-\mathrm{bq}_{\mathrm{i}}-\mathrm{dq}_{\mathrm{j}}\right) \mathrm{q}_{\mathrm{i}}-\mathrm{cq}_{\mathrm{i}}+\mathrm{s}_{\mathrm{i}} \mathrm{q}_{\mathrm{i}}, \mathrm{i}=1$,2. Firm i's best response function is given by $\mathrm{BR}_{\mathrm{i}}\left(\mathrm{q}_{\mathrm{j}}, \mathrm{s}_{\mathrm{i}}\right)=\left(\mathrm{a}-\mathrm{c}+\mathrm{s}_{\mathrm{i}}-\mathrm{dq}_{\mathrm{j}}\right) / 2 \mathrm{~b}, \mathrm{i}=1,2$. The Cournot-Nash equilibrium is symmetric with output levels, profits and government payoffs (for arbitrary subsidies of $\left(\mathrm{s}_{1}, \mathrm{~s}_{2}\right)$ ) as shown in Table A3 in the Appendix.

Differentiating $\mathrm{w}_{\mathrm{i}}{ }^{\mathrm{CN}}\left(\mathrm{s}_{1}, \mathrm{~s}_{2}\right)$ with respect to $\mathrm{s}_{\mathrm{i}}$, invoking symmetry $\left(\mathrm{s}_{1}{ }^{\mathrm{CN}}=\mathrm{s}_{2}{ }^{\mathrm{CN}}\right)$ and solving yields $\mathrm{s}_{1}{ }^{\mathrm{CN}}=\mathrm{s}_{2}{ }^{\mathrm{CN}}=\mathrm{d}^{2}(\mathrm{a}-\mathrm{c}) /\left[4 \mathrm{~b}^{2}+2 \mathrm{bd}-\mathrm{d}^{2}\right]$. Notice that $\mathrm{s}_{\mathrm{i}}{ }^{\mathrm{CN}}>0$ whether the goods are substitutes or complements: governments want to subsidize when the firms use quantity strategies (and tax when the firms use price strategies; see Eaton and Grossman, 1986), independent of the nature of the goods. Thus, it is not true that the governments want to subsidize when the firms' strategies are strategic substitutes and tax when they are strategic complements: the dichotomy that proved useful in the industrial organization context is not the pertinent one in international trade. Moreover, since the governments' strategies are strategic substitutes when and only when their firms' strategies are strategic substitutes, it is not true that the governments want to subsidize when the governments' strategies are strategic substitutes and tax when they are strategic complements. Substituting $\mathrm{s}_{\mathrm{i}}^{\mathrm{CN}}$ into the results displayed in Table A3 yields Table A4 (see the Appendix), which provides the reduced-form equilibrium outputs, profits and government payoffs when the equilibrium subsidies 
are used.

To determine the firms' and governments' preferences over trade regime, we compare $\pi^{\mathrm{CN} *}$ and $\mathrm{w}^{\mathrm{CN} *}$ with $\Pi^{\mathrm{CN} *}$ and $\mathrm{W}^{\mathrm{CN} *}$, respectively, using Tables $\mathrm{A} 2$ and $\mathrm{A} 4$. It is straightforward to verify that:

(1) $\pi^{\mathrm{CN} *}>\Pi^{\mathrm{CN} *}$ for all $d$ (that is, firms prefer to be subsidized irrespective of the nature of the good); and

(2) $\mathrm{W}^{\mathrm{CN} *}>\mathrm{W}^{\mathrm{CN} *}$ for $\mathrm{d}>0$ (that is, governments prefer free trade when the goods are substitutes) but $\mathrm{w}^{\mathrm{CN} *}>\mathrm{W}^{\mathrm{CN} *}$ for $\mathrm{d}<0$ (that is, governments prefer a subsidy regime when the goods are complements).

\section{Solution of the Subsidy Regime Game under Sequential-move Markets}

To our knowledge, this version of the strategic trade game has not been addressed in the previous literature. Eaton and Grossman (1986) come closest when they consider a simultaneousmove market under the hypothesis of "consistent conjectures;" that is, they assume that each firm's conjectural variation parameter is equal to the slope of the rival firm's best-response function. ${ }^{7}$ They find that if both firms have consistent conjectural variations, then the equilibrium subsidy rates are zero. An intermediate finding on the way to this result is that if any single firm has consistent conjectures about its rival (or, what is formally equivalent, if that firm is a Stackelberg leader), then that firm's government will neither tax nor subsidize its firm. This corresponds to one of our findings below. However, they do not continue with the analysis of the Stackelberg case, but

${ }^{7}$ This approach to modeling oligopoly behavior in a static setting is not uncontroversial; see Daughety (1985) and Makowski (1987). 
proceed with the case of consistent conjectures on the part of both firms, leading to the result that free trade is an equilibrium among the governments. What we show below is that, in the Stackelberg case, free trade is not a Nash equilibrium among the governments. Although the government of the Stackelberg leader firm neither taxes nor subsidizes its firm, the follower firm's government (in our quantity model) does subsidize its firm; this is sometimes advantageous and sometimes disadvantageous for the leader firm's government. We will provide the solution for the model with a sequential-move market structure and then compare it with the outcomes obtained in Sections 3 and 4 above.

For arbitrary subsidies $\left(\mathrm{s}_{1}, \mathrm{~s}_{2}\right)$, consider the sequential-move market game in which firm 1 is arbitrarily designated the Stackelberg leader. Profits for firm 2 (the Stackelberg follower) are given by $\pi_{2}\left(\mathrm{q}_{1}, \mathrm{q}_{2}, \mathrm{~s}_{2}\right)=\left(\mathrm{a}-\mathrm{bq}_{2}-\mathrm{dq}_{1}\right) \mathrm{q}_{2}-\mathrm{cq}_{2}+\mathrm{s}_{2} \mathrm{q}_{2}$. Firm 2's best response function is given by $\mathrm{BR}_{2}\left(\mathrm{q}_{2}, \mathrm{~s}_{2}\right)=\left(\mathrm{a}-\mathrm{c}+\mathrm{s}_{2}-\mathrm{dq}_{1}\right) / 2 \mathrm{~b}$. Thus, $\left.\pi_{1}\left(\mathrm{q}_{1}, \mathrm{BR}_{2}\left(\mathrm{q}_{1}, \mathrm{~s}_{2}\right), \mathrm{s}_{1}\right)=\left(\mathrm{a}-\mathrm{bq}_{1}-\mathrm{d}\left(\mathrm{a}-\mathrm{c}+\mathrm{s}_{2}-\mathrm{dq}_{1}\right) / 2 \mathrm{~b}\right)\right) \mathrm{q}_{1}-$ $\mathrm{cq}_{1}+\mathrm{s}_{1} \mathrm{q}_{1}$. The Stackelberg equilibrium output levels, firm profits and government payoffs when firm 1 is the leader and firm 2 is the follower are shown in Table A5 in the Appendix.

Note that now the governments' payoffs differ from those of their domestic firms, because government welfare is domestic firm profits minus subsidies paid. Setting the derivative of $\mathrm{w}_{1}{ }^{\mathrm{L}}\left(\mathrm{s}_{1}, \mathrm{~s}_{2}\right)$ with respect to $\mathrm{s}_{1}$ equal to zero and simplifying yields the first-order condition: $-2 \mathrm{bs}_{1}=$ 0 for all $\mathrm{s}_{2}$. Thus, we find that it is a dominant strategy for a government to neither tax nor subsidize its domestic firm when that firm is a Stackelberg leader in the product market. ${ }^{8}$

The intuition behind this result is as follows. Recall that government 1's payoff is given by

8 This result is quite general; it holds for substitutes and complements, quantity and price strategies, and arbitrary demand and cost functions (as long as the first-order conditions characterize the optima and second-order conditions hold with strict inequalities). 
$\mathrm{w}_{1}^{\mathrm{L}}\left(\mathrm{s}_{1}, \mathrm{~s}_{2}\right)=\pi_{1}^{\mathrm{L}}\left(\mathrm{q}_{1}^{\mathrm{L}}\left(\mathrm{s}_{1}, \mathrm{~s}_{2}\right), \mathrm{BR}_{2}\left(\mathrm{q}_{1}^{\mathrm{L}}\left(\mathrm{s}_{1}, \mathrm{~s}_{2}\right), \mathrm{s}_{2}\right), \mathrm{s}_{1}\right)-\mathrm{s}_{1} \mathrm{q}_{1}^{\mathrm{L}}\left(\mathrm{s}_{1}, \mathrm{~s}_{2}\right)$. This payoff depends on $\mathrm{s}_{1}$ both directly and indirectly through $\mathrm{q}_{1}{ }^{\mathrm{L}}\left(\mathrm{s}_{1}, \mathrm{~s}_{2}\right)$. Moreover, firm 2 plays a best response which depends on $\mathrm{q}_{1}$ and $\mathrm{s}_{2}$, but not directly on $\mathrm{s}_{1}$. Essentially, government 1 can only influence firm 2 indirectly through its impact on $\mathrm{q}_{1}{ }^{\mathrm{L}}$, which then affects firm 2's best response $\mathrm{BR}_{2}$. If firm 1 is a Stackelberg leader, it already takes this impact of $\mathrm{q}_{1}{ }^{\mathrm{L}}$ on $\mathrm{BR}_{2}$ into account in its choice of $\mathrm{q}_{1}{ }^{\mathrm{L}}$. Firm 1's government cannot do any more than firm 1 has already done to influence $\mathrm{q}_{2}$. More formally, by the envelope theorem (since $\pi_{1}^{\mathrm{L}}$ is already maximized by $\mathrm{q}_{1}^{\mathrm{L}}$ ), the optimal $\mathrm{s}_{1}$ solves:

$$
\begin{array}{r}
\partial \mathrm{w}_{1}{ }^{\mathrm{L}}\left(\mathrm{s}_{1}, \mathrm{~s}_{2}\right) / \partial \mathrm{s}_{1}=\partial \pi_{1}{ }^{\mathrm{L}}\left(\mathrm{q}_{1}{ }^{\mathrm{L}}\left(\mathrm{s}_{1}, \mathrm{~s}_{2}\right), \mathrm{BR}_{2}\left(\mathrm{q}_{1}{ }^{\mathrm{L}}\left(\mathrm{s}_{1}, \mathrm{~s}_{2}\right), \mathrm{s}_{2}\right), \mathrm{s}_{1}\right) / \partial \mathrm{s}_{1} \\
-\mathrm{q}_{1}^{\mathrm{L}}\left(\mathrm{s}_{1}, \mathrm{~s}_{2}\right)-\mathrm{s}_{1}\left\{\partial \mathrm{q}_{1}{ }^{\mathrm{L}}\left(\mathrm{s}_{1}, \mathrm{~s}_{2}\right) / \partial \mathrm{s}_{1}\right\}=0 .
\end{array}
$$

Since $\partial \pi_{1}{ }^{\mathrm{L}}\left(\mathrm{q}_{1}{ }^{\mathrm{L}}\left(\mathrm{s}_{1}, \mathrm{~s}_{2}\right), \mathrm{BR}_{2}\left(\mathrm{q}_{1}{ }^{\mathrm{L}}\left(\mathrm{s}_{1}, \mathrm{~s}_{2}\right), \mathrm{s}_{2}\right), \mathrm{s}_{1}\right) / \partial \mathrm{s}_{1}=\mathrm{q}_{1}{ }^{\mathrm{L}}$, this reduces to:

$$
\partial \mathrm{w}_{1}{ }^{\mathrm{L}}\left(\mathrm{s}_{1}, \mathrm{~s}_{2}\right) / \partial \mathrm{s}_{1}=-\mathrm{s}_{1}\left\{\partial \mathrm{q}_{1}{ }^{\mathrm{L}}\left(\mathrm{s}_{1}, \mathrm{~s}_{2}\right) / \partial \mathrm{s}_{1}\right\}=0 .
$$

Since $\partial \mathrm{q}_{1}{ }^{\mathrm{L}}\left(\mathrm{s}_{1}, \mathrm{~s}_{2}\right) / \partial \mathrm{s}_{1}>0$, it follows that the optimal $\mathrm{s}_{1}=0$ for all $\mathrm{s}_{2}$.

This result simplifies the determination of government 2's optimal subsidy rate $\mathrm{s}_{2}$, since we can substitute $\mathrm{s}_{1}{ }^{\mathrm{L}}=0$ into government 2 s objective function $\mathrm{W}_{2}^{\mathrm{F}}\left(\mathrm{s}_{1}, \mathrm{~s}_{2}\right)$ before proceeding. Differentiating $\mathrm{w}_{2}^{\mathrm{F}}\left(0, \mathrm{~s}_{2}\right)$ with respect to $\mathrm{s}_{2}$, setting the resulting first-order condition equal to zero and solving yields $\mathrm{s}_{2}{ }^{\mathrm{F}}=(\mathrm{a}-\mathrm{c}) \mathrm{d}^{2}\left[4 \mathrm{~b}^{2}-2 \mathrm{bd}-\mathrm{d}^{2}\right] /\left(4 \mathrm{~b}^{2}-\mathrm{d}^{2}\right)\left(4 \mathrm{~b}^{2}-3 \mathrm{~d}^{2}\right)$. Since $|\mathrm{d}|<\mathrm{b}$ and $\mathrm{a}>\mathrm{c}$, it follows that each term in this expression is positive. Thus, regardless of whether the goods are substitutes or complements, the follower firm's government will subsidize its production. Substituting the equilibrium subsidy levels into Table A5 yields Table A6 (see the Appendix), which provides equilibrium quantities, profits and government payoffs when equilibrium subsidies are employed.

A little algebra shows that, in a regime of equilibrium subsidies, the Stackelberg leader's 
output level is less than that of the Stackelberg follower. This is in contrast to the case under free trade, in which the Stackelberg leader produces more than the Stackelberg follower. The Stackelberg leader's incentive to produce more than the follower in the usual (equal marginal cost) case is overwhelmed by the cost advantage enjoyed by the follower whose production is subsidized (while that of the leader is not).

We can now determine the firms' and their governments' preference orderings over roles (Stackelberg leader versus Cournot-Nash player versus Stackelberg follower) and over free trade versus a regime of subsidies. First, consider firm preferences over roles. It can be shown that $\pi^{\mathrm{F} *}$ $>\pi^{\mathrm{CN} *}>\pi^{\mathrm{L} *}$; that is, Stackelberg leadership is strongly disadvantageous in a regime of subsidies. For both substitutes and complements, the Cournot-Nash profits are between those of the leader and follower. Moreover, as was true of the output levels, the follower's profit exceeds the leader's profit. Further note that these results hold independent of the sign of $d$ (that is, for substitutes as well as complements). Next, consider government preferences over roles. It can be shown that $\mathrm{w}^{\mathrm{F} *}$ $>\mathrm{w}^{\mathrm{CN} *}>\mathrm{w}^{\mathrm{L} *}$ for $\mathrm{d}>0$ (that is, when the goods are substitutes) and $\mathrm{w}^{\mathrm{L} *}>\mathrm{w}^{\mathrm{F} *}>\mathrm{w}^{\mathrm{CN} *}$ for $\mathrm{d}<0$ (that is, when the goods are complements). That is, Stackelberg leadership on the part of its domestic firm is advantageous to a government if the goods are complements and disadvantageous if the goods are substitutes. In the case of substitutes, the government's payoff under a simultaneousmove market structure is between those when its domestic firm is follower and leader, respectively; in the case of complements, the government least prefers the simultaneous-move market structure. We summarize these results in Proposition 1 (see the Web Appendix for the proof).

Proposition 1:

(a) $\pi^{\mathrm{F} *}>\pi^{\mathrm{CN} *}>\pi^{\mathrm{L} *}$ for all $\mathrm{d}$; 
(b) $\mathrm{w}^{\mathrm{F} *}>\mathrm{w}^{\mathrm{CN} *}>\mathrm{w}^{\mathrm{L} *}$ for $\mathrm{d}>0$ and $\mathrm{w}^{\mathrm{L} *}>\mathrm{w}^{\mathrm{F} *}>\mathrm{w}^{\mathrm{CN} *}$ for $\mathrm{d}<0$.

Next, consider firms' and their governments' preferences over free trade versus subsidies. Evaluating equilibrium profits for a Stackelberg leader in these two regimes and comparing implies that $\Pi^{\mathrm{L} *}>\pi^{\mathrm{L} *}$ if $\mathrm{d}>0$ and $\Pi^{\mathrm{L} *}<\pi^{\mathrm{L} *}$ if $\mathrm{d}<0$. That is, a Stackelberg leader prefers free trade when the goods are substitutes, and prefers a subsidy regime when the goods are complements. Evaluating equilibrium profits for a Stackelberg follower in these two regimes and comparing implies that $\pi^{\mathrm{F} *}$ $>\Pi^{\mathrm{F} *}$ for all d. Thus, a Stackelberg follower firm always prefers a subsidy regime to free trade.

Since the government of a Stackelberg leader does not subsidize its firm even in a subsidy regime, the equilibrium payoffs for the government of a Stackelberg leader under free trade and a subsidy regime are the same as those of their domestic firms. Thus, $\mathrm{W}^{\mathrm{L} *}>\mathrm{w}^{\mathrm{L} *}$ if $\mathrm{d}>0$ and $\mathrm{W}^{\mathrm{L} *}$ $<w^{L *}$ if $d<0$. That is, the government of a Stackelberg leader prefers free trade when the goods are substitutes, and prefers a subsidy regime when the goods are complements. Finally, evaluating the equilibrium payoffs for the government of a Stackelberg follower under free trade and a subsidy regime and comparing yields $\mathrm{w}^{\mathrm{F} *}>\mathrm{W}^{\mathrm{F} *}$ for all $\mathrm{d}$; this follows from the fact that $\mathrm{W}^{\mathrm{F} *}=\mathrm{w}_{2}{ }^{\mathrm{F}}(0,0)$ while $\mathrm{w}^{\mathrm{F} *}=\max _{2} \mathrm{~F}_{2}^{\mathrm{F}}\left(0, \mathrm{~s}_{2}\right)$. Note that this result really only depends upon the fact that the leader's government has a dominant strategy to choose $\mathrm{s}_{1}$ to be zero, and not upon the precise form of the demand and cost functions, the nature of the good or the strategy space involved: the leader's government will choose non-intervention and the follower's government will choose intervention. We summarize these results in Proposition 2 (see the Web Appendix for the proof).

\section{Proposition 2:}

(a) $\Pi^{\mathrm{L} *}>\pi^{\mathrm{L} *}$ if $d>0$ and $\Pi^{\mathrm{L} *}<\pi^{\mathrm{L} *}$ if $d<0$, while $\pi^{\mathrm{F} *}>\Pi^{\mathrm{F} *}$ for all $\mathrm{d}$;

(b) $\mathrm{W}^{\mathrm{L} *}>\mathrm{w}^{\mathrm{L} *}$ if $\mathrm{d}>0$ and $\mathrm{W}^{\mathrm{L} *}<\mathrm{w}^{\mathrm{L} *}$ if $\mathrm{d}<0$, while $\mathrm{w}^{\mathrm{F} *}>\mathrm{W}^{\mathrm{F} *}$ for all $\mathrm{d}$. 
6. Comparisons: Firm and Government Preferences over Firm Roles and Government Policies

We now collect the standard results reiterated in Sections 3 and 4, and the new results generated in Section 5, into two summary tables that allow us to address the following new questions: (1) What is the impact of allowing subsidies (as compared to free trade) on firm and government preferences over firm roles? (2) What is the impact of a sequential-move market structure (as compared to a simultaneous-move market structure) on firm and government preferences over free trade versus a subsidy regime?

Table 1 addresses the first question; it lists firm and government preference orderings over roles. The nature of the goods (substitutes versus complements) is indicated along the left-hand-side of the table, and the two possible trade regimes are listed across the top of the table.

\section{Table 1: Impact of Trade Regime on Firm and Government Preferences over Firm Roles}

\begin{tabular}{|c|c|c|}
\cline { 2 - 3 } \multicolumn{1}{c|}{} & Equilibrium $\mathrm{w}$. Free Trade & Equilibrium $\mathrm{w}$. Subsidies \\
\hline \multirow{2}{*}{ d $>0$} & $\mathrm{~W}^{\mathrm{L} *}>\mathrm{W}^{\mathrm{CN} *}>\mathrm{W}^{\mathrm{F} *}$ & $\mathrm{w}^{\mathrm{F} *}>\mathrm{w}^{\mathrm{CN} *}>\mathrm{w}^{\mathrm{L} *}$ \\
\cline { 2 - 3 } & $\Pi^{\mathrm{L} *}>\Pi^{\mathrm{CN} *}>\Pi^{\mathrm{F} *}$ & $\pi^{\mathrm{F} *}>\pi^{\mathrm{CN} *}>\pi^{\mathrm{L} *}$ \\
\hline $\mathrm{d}<0$ & $\mathrm{~W}^{\mathrm{F} *}>\mathrm{W}^{\mathrm{L} *}>\mathrm{W}^{\mathrm{CN} *}$ & $\mathrm{w}^{\mathrm{L} *}>\mathrm{w}^{\mathrm{F} *}>\mathrm{w}^{\mathrm{CN} *}$ \\
\cline { 2 - 3 }$($ Complements $)$ & $\Pi^{\mathrm{F} *}>\Pi^{\mathrm{L} *}>\Pi^{\mathrm{CN} *}$ & $\pi^{\mathrm{F} *}>\pi^{\mathrm{CN} *}>\pi^{\mathrm{L} *}$ \\
\hline
\end{tabular}

Under free trade, we recover the standard preference ordering over roles found in the industrial organization literature; moreover, since the government payoffs are the same as the firm profits, the governments share the preferences of their domestic firms. When the goods are substitutes, a firm prefers the role of Stackelberg leader to the role of Cournot-Nash player, which is preferred to the role of Stackelberg follower. That is, Stackelberg leader profits exceed CournotNash profits which exceed Stackelberg follower profits. When the goods are complements, a firm 
prefers the role of Stackelberg follower to the role of Stackelberg leader, which is preferred to the role of Cournot-Nash player. That is, Stackelberg follower profits exceed Stackelberg leader profits, which exceed Cournot-Nash profits. In this latter case, both firms agree that the sequential-move structure is preferred to the simultaneous-move one, but each firm prefers to be the follower rather than the leader.

As shown in this paper, under a regime of subsidies, two key differences can arise. First, firms' preferences over roles may change. We find that a firm always (independent of whether the goods are substitutes or complements) prefers the role of Stackelberg follower to the role of Cournot-Nash player, which is preferred to the role of Stackelberg leader. This preference ordering has changed from the free trade case, both for substitutes and complements. For substitutes, the preference ordering is completely reversed from the free trade case. For complements, only the preferences between the Cournot-Nash role and the Stackelberg leader role are reversed; a firm still most prefers the role of Stackelberg follower. In this case, the firms now disagree about the desirability of the sequential-move structure versus the simultaneous-move one.

Second, the payoffs of a government and its domestic firm may diverge, so it is possible that government preferences may differ from those of its domestic firm. We find that when the goods are substitutes, a government prefers (for its domestic firm) the role of Stackelberg follower to the role of Cournot-Nash firm, which is preferred to the role of Stackelberg leader. Thus, in this case, the government and its domestic firm continue to agree in their preferences regarding the firm's role (but these preferences are completely reversed relative to the free trade case). When the goods are complements, a government prefers (for its domestic firm) the role of Stackelberg leader to the role of Stackelberg follower, which is preferred to the role of Cournot-Nash player. In this case, the 
government and its domestic firm disagree, since the firm prefers the role of Stackelberg follower to the role of Cournot-Nash player, which is preferred to the role of Stackelberg leader.

To address the second question, we refer to Table 2, which lists firm and government preference orderings over trade regimes. The nature of the goods (substitutes versus complements) is listed along the left-hand-side and the two possible market structures are listed across the top.

Table 2: Impact of Market Structure on Firm and Government Preferences over Trade Regime

\begin{tabular}{|c|c|c|}
\hline & Simultaneous-Move & Sequential-Move \\
\hline \multirow{4}{*}{$\begin{array}{c}\quad d>0 \\
\text { (Substitutes) }\end{array}$} & \multirow{2}{*}{$\mathrm{W}^{\mathrm{CN} *}>\mathrm{W}^{\mathrm{CN}^{*}}$} & $\mathrm{~W}^{\mathrm{L} *}>\mathrm{W}^{\mathrm{L} *}$ \\
\hline & & $\mathrm{W}^{\mathrm{F} *}>\mathrm{W}^{\mathrm{F} *}$ \\
\hline & \multirow{2}{*}{$\pi^{\mathrm{CN} *}>\Pi^{\mathrm{CN} *}$} & $\Pi^{\mathrm{L} *}>\pi^{\mathrm{L} *}$ \\
\hline & & $\pi^{\mathrm{F} *}>\Pi^{\mathrm{F} *}$ \\
\hline \multirow{4}{*}{$\begin{array}{c}\mathrm{d}<0 \\
(\text { Complements })\end{array}$} & \multirow{2}{*}{$\mathrm{W}^{\mathrm{CN} *}>\mathrm{W}^{\mathrm{CN} *}$} & $\mathrm{~W}^{\mathrm{L} *}>\mathrm{W}^{\mathrm{L} *}$ \\
\hline & & $\mathrm{W}^{\mathrm{F} *}>\mathrm{W}^{\mathrm{F} *}$ \\
\hline & \multirow{2}{*}{$\pi^{\mathrm{CN} *}>\Pi^{\mathrm{CN} *}$} & $\pi^{\mathrm{L} *}>\Pi^{\mathrm{L} *}$ \\
\hline & & $\pi^{\mathrm{F} *}>\Pi^{\mathrm{F} *}$ \\
\hline
\end{tabular}

Under a Cournot-Nash market structure, we find the usual results from strategic trade theory. Firms always prefer a regime of subsidies; governments prefer a regime of subsidies when the goods are complements, but prefer free trade when the goods are substitutes. Thus, when the goods are complements, both firms and both governments agree that a regime of subsidies is preferable to free trade. However, when the goods are substitutes, the firms and their respective governments will disagree about the desirability of free trade, with the governments preferring free trade. Although subsidizing is a dominant strategy in a one-shot game, it is clear that the governments could resolve this prisoners' dilemma using trigger strategies that rely on behavior only in the instant market 
(since each government can punish the other government by reverting to subsidizing its firm).

When the market structure involves sequential timing, we find that a government and its domestic firm will never be in conflict about the desirability of free trade. When the goods are complements, both firms and their governments prefer a regime of subsidies (as they do in the simultaneous-move case). When the goods are substitutes, profits for a Stackelberg leader (and its government's payoff) are higher under free trade than in a regime of subsidies; however, profits for a Stackelberg follower (and its government's payoff) are lower under free trade than in a regime of subsidies. In this case (and in contrast to the simultaneous-move case), the two governments do not agree on the desirability of free trade. Moreover, we found that it was a dominant strategy for the government of the Stackelberg leader firm to offer a subsidy of zero even in a subsidy regime. Thus, in trying to maintain a regime of free trade, the government of the leader firm cannot use a strategy of reverting to the subsidy regime in order to punish the government of the follower firm (since a subsidy of zero is the leader's government's optimal strategy in both regimes). Any sort of trigger strategy policy must link across different markets, where the leader in some markets is a follower in others. Then a deviation from free trade by government $\mathrm{i}$ in a market wherein firm $\mathrm{j}$ is a leader can be punished by a deviation from free trade by government $\mathrm{j}$ in a market wherein firm $\mathrm{i}$ is a leader. In the Web Appendix we provide a proof of Proposition 3.

$$
\text { Proposition 3: } \mathrm{W}^{\mathrm{L} *}+\mathrm{W}^{\mathrm{F} *}>\mathrm{w}^{\mathrm{L} *}+\mathrm{w}^{\mathrm{F} *} \text { when } \mathrm{d}>0 \text {. }
$$

That is, if there are two "third-country markets" in which the firms compete, with each being a leader in one market and a follower in the other, then both governments would prefer (and could support) a regime of free trade by using trigger strategies of the form: do not subsidize in either market unless the other government has subsidized in some market; if the other government has 
subsidized in some market, then revert to subsidizing in the market in which your domestic firm is a follower (since it is a dominant strategy to neither tax nor subsidize in the market in which your domestic firm is a leader).

One final observation to be made about the basic model with quantity strategies, in which market structure is exogenously-specified, is that government trade policy can be determined both by the nature of the goods and the market structure. If the goods are substitutes and the firms move simultaneously, then both governments will engage in free trade (e.g., supported by trigger strategies); if the goods are substitutes and the firms move sequentially, then the governments will disagree about the desirability of free trade, and hence it will be unsustainable; the governments will end up in a subsidy regime. In the case of complementary goods, the governments are always unified in their preference for the subsidy regime, independent of the market structure.

\section{Endogenous Role Choice}

We have heretofore assumed that the firms' roles as Stackelberg leader and follower were exogenous, or dictated by considerations outside of this particular market. As mentioned in the Introduction, there are many models which obtain sequential play as an equilibrium outcome, beginning from firms that are ex ante identical (see footnote 2). We consider the simpler question of when a firm which has an option to be a leader will choose to employ or decline that option. This decision is envisioned as being made in advance of the governments' tax/subsidy and the firms' quantity/price decisions. Thus, the decision to become a leader or to decline this option is assumed to be made at the beginning, when the product is just being introduced to the third country.

We assume that one firm (without loss of generality, from country 1) first conceives the idea 
of a product that is new to the third country, and we view this firm as having the opportunity to make a strategic investment that would facilitate its market leadership. ${ }^{9}$ This firm may be a technological innovator, which has discovered how to produce the new product; this would favor firms from countries that invent new products as potential leaders. Alternatively, the firm may be a marketing innovator, which has developed expertise about the kind of products that would gain broad acceptance in the third country; this would tend to favor firms from countries that share similar cultural, religious, and taste attributes as potential leaders and/or firms who are willing to make the investment to develop such information.

If the firm with the option to move first exercises this option, then the market structure will be a Stackelberg leader-follower one, while if the firm with the option to move first chooses not to exercise this option, then the market structure will be a Cournot one. In terms of the governments' choices, we consider a single third-country market, so that multi-market trigger strategies (of the sort discussed in Section 6) may not be invoked to support free trade. However, if both governments would prefer free trade to a regime of bilateral subsidies, then trigger strategies based on this single market could be used to support free trade, and we will allow this level of coordination by the governments.

The game form we consider is as follows. First, the potential leader (say, firm 1) decides, once and for all, upon its role: "Leader" or "Cournot." Then the governments choose their subsidy levels, and finally the firms choose their output levels (in sequence if firm 1 has chosen Leader and simultaneously if firm 1 has chosen Cournot); we refer to this as the "one-shot strategic trade game."

9 For example, recall our discussion in the Introduction concerning how strategic investments in information-generating activities can yield informational asymmetries that give rise to mutually advantageous sequential-move market structures. 
The second and third stages may be viewed as being repeated infinitely often, so the governments may use trigger strategies to support free trade if they both prefer this outcome to that under a regime of bilateral subsidies.

We begin with the case of substitute goods. If firm 1 chooses Leader, then the equilibrium in the one-shot strategic trade game involves a subsidy regime with payoffs of $\left(\mathrm{w}^{\mathrm{L} *}, \mathrm{w}^{\mathrm{F} *}\right)$ for the governments. Moreover, firm 2's government prefers this to free trade (see Table 2), so the equilibrium is the same under repeated play. Thus, if firm 1 chooses Leader, then it anticipates a payoff of $\pi^{\mathrm{L} *}$. On the other hand, if firm 1 chooses Cournot, then the equilibrium in the one-shot strategic trade game involves a subsidy regime with payoffs of $\left(\mathrm{w}^{\mathrm{CN} *}, \mathrm{w}^{\mathrm{CN} *}\right)$ for the governments. However, in this case both governments prefer free trade, and will employ trigger strategies in the repeated game to support it. Thus, if firm 1 chooses Cournot, then it anticipates a payoff of $\Pi^{\mathrm{CN} *}$. Since $\Pi^{\mathrm{CN} *}>\pi^{\mathrm{L} *}$ for the case of substitute goods and quantity strategies (see the proof of Proposition 4 in the Web Appendix), firm 1 chooses Cournot, and the trade regime is free trade.

Now consider the case of complementary goods. If firm 1 chooses Leader, then the equilibrium in the one-shot strategic trade game involves a subsidy regime with payoffs of $\left(\mathrm{w}^{\mathrm{L} *}\right.$, $\mathrm{W}^{\mathrm{F} *}$ ) for the governments. Now both governments prefer this to free trade (see Table 2), so the equilibrium is the same under repeated play. Thus, if firm 1 chooses Leader, then it anticipates a payoff of $\pi^{\mathrm{L} *}$. On the other hand, if firm 1 chooses Cournot, then the equilibrium in the one-shot strategic trade game involves a subsidy regime with payoffs of $\left(\mathrm{w}^{\mathrm{CN} *}, \mathrm{w}^{\mathrm{CN} *}\right)$ for the governments. Again, they both prefer this to free trade, and so again the equilibrium is the same under repeated play. Thus, if firm 1 chooses Cournot, then it anticipates a payoff of $\pi^{\mathrm{CN} *}$. Since $\pi^{\mathrm{CN} *}>\pi^{\mathrm{L} *}$ for the case of complementary goods and quantity strategies (see Table 1), firm 1 chooses Cournot and 
the trade regime involves subsidies.

We summarize these findings in Proposition 4, which is proved in the Web Appendix.

Proposition 4: The potential leader will choose the Cournot role; the equilibrium trade regime will be free trade when the products are substitutes and bilateral subsidies when the products are complements.

Since market structure is endogenous in this game form, the equilibrium trade regime depends only on the nature of the goods; independent of the nature of the goods, the potential leader defers its decision in order to effect the Cournot-Nash market structure.

8. Summary of Results When Price is the Strategic Market Variable

Here we briefly summarize the analogous results to those of Section 6 and 7 for the case in which firms compete in price strategies; details can be found in Balboa (in progress), wherein a result analogous to that shown in Section 5 is proved: independent of the nature of the goods, both governments tax their firms when the market structure is simultaneous-move (that is, $\mathrm{s}^{\mathrm{CN}}<0$ ); when the market structure involves sequential moves, the leader's government neither taxes nor subsidizes its firm, while the follower's government taxes its firm. Table 3 summarizes the firms' and their governments' preferences over market structure, given the trade regime. Having verified that taxes (that is, negative subsidies) will be employed, to avoid confusion with our previous results, we now use the word "taxes" where "subsidies" was used earlier. 
Table 3: Impact of Trade Regime on Firm and Government Preferences over Firm Roles

\begin{tabular}{|c|c|c|}
\cline { 2 - 3 } \multicolumn{1}{c|}{} & Equilibrium w. Free Trade & Equilibrium w. Taxes \\
\hline \multirow{2}{*}{$\begin{array}{c}\text { price model } \\
\text { (Substitutes) }\end{array}$} & $\mathrm{W}^{\mathrm{F} *}>\mathrm{W}^{\mathrm{L} *}>\mathrm{W}^{\mathrm{CN} *}$ & $\mathrm{w}^{\mathrm{L} *}>\mathrm{w}^{\mathrm{F} *}>\mathrm{w}^{\mathrm{CN} *}$ \\
\cline { 2 - 3 } & $\Pi^{\mathrm{F} *}>\Pi^{\mathrm{L} *}>\Pi^{\mathrm{CN} *}$ & $\pi^{\mathrm{L} *}>\pi^{\mathrm{CN} *}>\pi^{\mathrm{F} *}$ \\
\hline price model & $\mathrm{W}^{\mathrm{L} *}>\mathrm{W}^{\mathrm{CN} *}>\mathrm{W}^{\mathrm{F} *}$ & $\mathrm{w}^{\mathrm{F} *}>\mathrm{w}^{\mathrm{CN} *}>\mathrm{w}^{\mathrm{L} *}$ \\
\cline { 2 - 3 } & $\Pi^{\mathrm{L} *}>\Pi^{\mathrm{CN} *}>\Pi^{\mathrm{F} *}$ & $\pi^{\mathrm{L} *}>\pi^{\mathrm{CN} *}>\pi^{\mathrm{F} *}$ \\
\hline
\end{tabular}

Under free trade, switching from quantity to price strategies merely converts strategic substitutes to strategic complements (and thus, the results for substitutes in the price model correspond to those for complements in the quantity model, as can be seen by comparing the relevant entries in Tables 1 and 3). However, this is not the case under a regime of taxes; while the same conversion works for the governments' payoffs, the firms' payoffs are affected differently because their governments apply different tax rates $\left(\mathrm{s}^{\mathrm{L}}=0\right.$ for the leader's government and $\mathrm{s}^{\mathrm{F}}<0$ for the follower's government), and thus they compete with different effective marginal costs, when the market structure is sequential. Using quantity strategies, the relevant preference ordering is $\pi^{\mathrm{F} *}$ $>\pi^{\mathrm{CN} *}>\pi^{\mathrm{L} *}$, while the corresponding preference ordering using price strategies is $\pi^{\mathrm{L} *}>\pi^{\mathrm{CN} *}>$ $\pi^{\mathrm{F} *}$, independent of the nature of the goods.

Table 4 below summarizes the firms' and their governments' preferences over trade regime, given the market structure. 
Table 4: Impact of Market Structure on Firm and Government Preferences over Trade Regime

\begin{tabular}{|c|c|c|}
\cline { 2 - 3 } \multicolumn{1}{c|}{} & Simultaneous-Move & Sequential-Move \\
\hline \multirow{3}{*}{$\begin{array}{c}\text { price model } \\
\text { Substitutes })\end{array}$} & $\mathrm{w}^{\mathrm{CN} *}>\mathrm{W}^{\mathrm{CN} *}$ & $\mathrm{w}^{\mathrm{L} *}>\mathrm{W}^{\mathrm{L} *}$ \\
\cline { 2 - 3 } & $\Pi^{\mathrm{CN} *}>\pi^{\mathrm{CN} *}$ & $\mathrm{w}^{\mathrm{F} *}>\mathrm{W}^{\mathrm{F} *}$ \\
\cline { 3 - 3 } & & $\pi^{\mathrm{L} *}>\Pi^{\mathrm{L} *}$ \\
\hline \multirow{3}{*}{$\begin{array}{c}\text { price model } \\
\text { (Complements) }\end{array}$} & $\mathrm{W}^{\mathrm{CN} *}>\mathrm{w}^{\mathrm{CN} *}$ & $\Pi^{\mathrm{F} *}>\pi^{\mathrm{F} *}$ \\
\cline { 2 - 3 } & $\Pi^{\mathrm{CN} *}>\pi^{\mathrm{CN} *}$ & $\mathrm{~W}^{\mathrm{L} *}>\mathrm{w}^{\mathrm{L} *}$ \\
\cline { 3 - 3 } & & $\Pi^{\mathrm{L} *}>\pi^{\mathrm{L} *}$ \\
\hline
\end{tabular}

Again, the standard conversion between strategic substitutes and strategic complements does not apply to the outcomes under price and quantity strategies. That is, one cannot obtain Table 4 from Table 2 simply by associating the case of price strategies and substitute goods with that of quantity strategies and complementary goods. While the government preferences obey this conversion under a simultaneous-move market structure, again those of the firms do not: using quantity strategies, the relevant preference ordering is $\pi^{\mathrm{CN} *}>\Pi^{\mathrm{CN} *}$, while the corresponding preference ordering using price strategies is $\Pi^{\mathrm{CN} *}>\pi^{\mathrm{CN} *}$, independent of the nature of the goods. Under a sequential-move market structure, this conversion is further disrupted; while it is supported for the leader firm and its government (who have identical payoffs because $s^{\mathrm{L}}=0$ ), it is not supported for the follower firm, where the corresponding preference ordering is $\pi^{\mathrm{F} *}>\Pi^{\mathrm{F} *}$ for quantity strategies and $\Pi^{\mathrm{F} *}>\pi^{\mathrm{F} *}$ for price strategies, independent of the nature of the goods.

When market structure is exogenously given, then Table 4 implies that the equilibrium trade regime, under a Cournot-Nash market structure, will involve taxes when the goods are substitutes 
and free trade (via employment of trigger strategies on the part of the governments) when the goods are complements. On the other hand, when the market structure is sequential, then the equilibrium trade regime must involve taxes, since firm 2's government will not agree to free trade. These results are similar (but not identical) to those for quantity strategies. For both price and quantity strategies, a sequential-move market structure leads to government intervention. A simultaneous-move market structure leads to free trade (again, supported by trigger strategies) when the firms' strategies are strategic substitutes and to government intervention when the firms' strategies are strategic complements.

When market structure is endogenized as before, we find somewhat different results. When the firms competed in quantity strategies, the potential leader always chose the Cournot-Nash role and the equilibrium trade regime was free trade when the goods were substitutes and involved subsidies when the goods were complements. When the firms compete in prices, we find that there is even greater variation. When the goods are substitutes, firm 1 will choose the Leader role, and the equilibrium trade regime will involve taxes; when the goods are complements, firm 1 will choose the Cournot-Nash role, and the equilibrium trade regime will be free trade. The supporting arguments are provided in the Web Appendix.

\section{Conclusions}

In this paper we explored the interplay of market structure and government trade policy. We did this primarily in the context of a heterogenous goods duopoly model wherein governments first (noncooperatively) choose subsidy levels for their firms and then firms choose output levels, either sequentially (i.e., in a Stackelberg leader-follower model) or simultaneously (i.e., in a Cournot-Nash 
model). We also provided results when firms compete in prices (which means that equilibrium government subsidies are negative, that is, taxes). In both the quantity and price models we further allowed for endogenous market structure by considering a potential leader who can choose between the Leader and Cournot roles. In particular, we showed why a firm with the option to lead must be cognizant of not only the characteristics of the product market (both the nature of the good or service to be provided, and how a rival may respond) but also of the potential responses of its own, and the rival firm's, government.

Table 5 summarizes our findings. Each cell lists the equilibrium trade regime, denoted $\mathrm{F}$ for free trade, $\mathrm{S}$ for a subsidy regime and $\mathrm{T}$ for a tax regime, as an ordered pair, where the first entry assumes an exogenous market structure and the second entry assumes that the market structure is endogenously-determined. A dash means that the indicated market structure (play is simultaneous or sequential) does not arise endogenously in equilibrium for the specified strategy space (strategies are in quantities or in prices) and the specified demand structure (goods are substitutes or complements). Finally, an asterisk on a trade regime means that at least one government in the associated equilibrium sets its subsidy/tax to zero.

Table 5: Equilibrium Trade Regime and Market Structure

\begin{tabular}{|c|c|c|c|}
\cline { 3 - 4 } \multicolumn{2}{c|}{} & Simultaneous-Move & Sequential-Move \\
\hline \multirow{2}{*}{ Quantity Strategies } & Substitutes & $\mathrm{F}^{*}, \mathrm{~F}^{*}$ & $\mathrm{~S}^{*},-$ \\
\cline { 2 - 4 } & Complements & $\mathrm{S}, \mathrm{S}$ & $\mathrm{S}^{*},-$ \\
\hline \multirow{2}{*}{ Price Strategies } & Substitutes & $\mathrm{T},-$ & $\mathrm{T}^{*}, \mathrm{~T}^{*}$ \\
\cline { 2 - 4 } & Complements & $\mathrm{F}^{*}, \mathrm{~F}^{*}$ & $\mathrm{~T}^{*},-$ \\
\hline
\end{tabular}

From this table, we can see that the equilibrium trade regime can be characterized on the basis of whether firms' strategies are strategic substitutes or strategic complements when the market 
structure is fixed and simultaneous: free trade arises when the firms' strategies are strategic substitutes (e.g., quantity strategies and substitute goods or price strategies and complementary goods) and a subsidy/tax regime arises when the firms' strategies are strategic complements (e.g., quantity strategies and complementary goods or price strategies and substitute goods). When market structure is fixed and sequential, then the equilibrium trade regime never involves free trade; again, this occurs because the follower firm's government always prefers to intervene and the leader firm's government has no credible threat with which to try to maintain a free trade agreement (since it is a dominant strategy for it to neither subsidize nor tax its firm). Regardless of market structure, the subsidy is positive when firms choose quantities and negative (a tax) when they choose prices.

When market structure is also endogenous, a simultaneous-move market structure with free trade remains an equilibrium (and a sequential-move market structure is not robust) when the firms' strategies are strategic substitutes. When the firms' strategies are strategic complements, the equilibrium trade regime involves government intervention, although the use of quantity strategies leads to a simultaneous-move market structure (and subsidies) while the use of price strategies leads to a sequential-move market structure (and taxes). 


\section{Appendix}

Table A1: Simultaneous-Move (Cournot-Nash) Results for Free Trade $\left(\mathrm{s}_{1}=\underline{\mathrm{s}}_{2}=0\right.$ )

\begin{tabular}{|l|l|}
\hline $\mathrm{Q}^{\mathrm{CN} *}$ & $(\mathrm{a}-\mathrm{c}) /(2 \mathrm{~b}+\mathrm{d})$ \\
\hline$\Pi^{\mathrm{CN} *}$ & $\mathrm{~b}(\mathrm{a}-\mathrm{c})^{2} /(2 \mathrm{~b}+\mathrm{d})^{2}$ \\
\hline $\mathrm{W}^{\mathrm{CN} *}$ & $\mathrm{~b}(\mathrm{a}-\mathrm{c})^{2} /(2 \mathrm{~b}+\mathrm{d})^{2}$ \\
\hline
\end{tabular}

Table A2: Sequential-Move (Stackelberg) Results for Free Trade $\left(\mathrm{s}_{1}=\mathrm{s}_{2}=0\right)$

\begin{tabular}{|l|l|}
\hline$Q^{L *}$ & $(a-c)(2 b-d) / 2\left(2 b^{2}-d^{2}\right)$ \\
\hline$Q^{F *}$ & $(a-c)\left(4 b^{2}-2 b d-d^{2}\right) / 4 b\left(2 b^{2}-d^{2}\right)$ \\
\hline$\Pi^{L *}$ & $(a-c)^{2}(2 b-d)^{2} / 8 b\left(2 b^{2}-d^{2}\right)$ \\
\hline$\Pi^{F *}$ & $(a-c)^{2}\left(4 b^{2}-2 b d-d^{2}\right)^{2} / 16 b\left(2 b^{2}-d^{2}\right)^{2}$ \\
\hline$W^{L *}$ & $(a-c)^{2}(2 b-d)^{2} / 8 b\left(2 b^{2}-d^{2}\right)$ \\
\hline$W^{F *}$ & $(a-c)^{2}\left(4 b^{2}-2 b d-d^{2}\right)^{2} / 16 b\left(2 b^{2}-d^{2}\right)^{2}$ \\
\hline
\end{tabular}

Table A3: Simultaneous-Move (Cournot-Nash) Results for Arbitrary Subsidy Levels

\begin{tabular}{|l|l|}
\hline $\mathrm{q}_{\mathrm{i}}^{\mathrm{CN}}\left(\mathrm{s}_{1}, \mathrm{~s}_{2}\right)$ & {$\left[(\mathrm{a}-\mathrm{c})(2 \mathrm{~b}-\mathrm{d})+2 \mathrm{bs}_{\mathrm{i}}-\mathrm{ds}_{\mathrm{j}}\right] /\left(4 \mathrm{~b}^{2}-\mathrm{d}^{2}\right)$} \\
\hline$\pi_{\mathrm{i}}^{\mathrm{CN}}\left(\mathrm{s}_{1}, \mathrm{~s}_{2}\right)$ & $\mathrm{b}\left[(\mathrm{a}-\mathrm{c})(2 \mathrm{~b}-\mathrm{d})+2 \mathrm{bs}_{\mathrm{i}}-\mathrm{ds}_{\mathrm{j}}\right]^{2} /\left(4 \mathrm{~b}^{2}-\mathrm{d}^{2}\right)^{2}$ \\
\hline $\mathrm{w}_{\mathrm{i}}^{\mathrm{CN}}\left(\mathrm{s}_{1}, \mathrm{~s}_{2}\right)$ & $\mathrm{b}\left[(\mathrm{a}-\mathrm{c})(2 \mathrm{~b}-\mathrm{d})+2 \mathrm{bs}_{\mathrm{i}}-d \mathrm{~s}_{\mathrm{j}}\right]^{2} /\left(4 \mathrm{~b}^{2}-\mathrm{d}^{2}\right)^{2}-\mathrm{s}_{\mathrm{i}}\left[(\mathrm{a}-\mathrm{c})(2 \mathrm{~b}-\mathrm{d})+2 \mathrm{bs}_{\mathrm{i}}-\mathrm{ds}_{\mathrm{j}}\right] /\left(4 \mathrm{~b}^{2}-\mathrm{d}^{2}\right)$ \\
\hline
\end{tabular}

Table A4: Simultaneous-Move (Cournot-Nash) Results for Equilibrium Subsidy Levels

\begin{tabular}{|l|l|}
\hline$q^{\mathrm{CN} *}$ & $2 b(a-c) /\left(4 b^{2}+2 b d-d^{2}\right)$ \\
\hline$\pi^{\mathrm{CN} *}$ & $4 b^{3}(a-c)^{2} /\left(4 b^{2}+2 b d-d^{2}\right)^{2}$ \\
\hline$w^{\mathrm{CN} *}$ & $2 b(a-c)^{2}\left(2 b^{2}-d^{2}\right) /\left(4 b^{2}+2 b d-d^{2}\right)^{2}$ \\
\hline
\end{tabular}


Table A5: Sequential-Move (Stackelberg) Results for Arbitrary Subsidy Levels

\begin{tabular}{|c|c|}
\hline $\mathrm{q}_{1}^{\mathrm{L}}\left(\mathrm{s}_{1}, \mathrm{~s}_{2}\right)$ & {$\left[(a-c)(2 b-d)+2 b s_{1}-d s_{2}\right] / 2\left(2 b^{2}-d^{2}\right)$} \\
\hline $\mathrm{q}_{2}^{\mathrm{F}}\left(\mathrm{s}_{1}, \mathrm{~s}_{2}\right)$ & {$\left[(a-c)\left(4 b^{2}-2 b d-d^{2}\right)+\left(4 b^{2}-d^{2}\right) s_{2}-2 b d s_{1}\right] / 4 b\left(2 b^{2}-d^{2}\right)$} \\
\hline$\pi_{1}^{\mathrm{L}}\left(\mathrm{s}_{1}, \mathrm{~s}_{2}\right)$ & {$\left[(a-c)(2 b-d)+2 b s_{1}-d s_{2}\right]^{2} / 8 b\left(2 b^{2}-d^{2}\right)$} \\
\hline$\pi_{2}^{\mathrm{F}}\left(\mathrm{s}_{1}, \mathrm{~s}_{2}\right)$ & {$\left[(a-c)\left(4 b^{2}-2 b d-d^{2}\right)+\left(4 b^{2}-d^{2}\right) s_{2}-2 b d s_{1}\right]^{2} / 16 b\left(2 b^{2}-d^{2}\right)^{2}$} \\
\hline $\mathrm{w}_{1}^{\mathrm{L}}\left(\mathrm{s}_{1}, \mathrm{~s}_{2}\right)$ & $\begin{array}{l}{\left[(a-c)(2 b-d)+2 b s_{1}-d s_{2}\right]^{2} / 8 b\left(2 b^{2}-d^{2}\right)} \\
-s_{1}\left[(a-c)(2 b-d)+2 b s_{1}-d s_{2}\right] / 2\left(2 b^{2}-d^{2}\right)\end{array}$ \\
\hline $\mathrm{w}_{2}^{\mathrm{F}}\left(\mathrm{s}_{1}, \mathrm{~s}_{2}\right)$ & $\begin{array}{l}{\left[(a-c)\left(4 b^{2}-2 b d-d^{2}\right)+\left(4 b^{2}-d^{2}\right) s_{2}-2 b d s_{1}\right]^{2} / 16 b\left(2 b^{2}-d^{2}\right)^{2}} \\
-s_{2}\left[(a-c)\left(4 b^{2}-2 b d-d^{2}\right)+\left(4 b^{2}-d^{2}\right) s_{2}-2 b d s_{1}\right] / 4 b\left(2 b^{2}-d^{2}\right)\end{array}$ \\
\hline
\end{tabular}

Table A6: Sequential-Move (Stackelberg) Results for Equilibrium Subsidy Levels

\begin{tabular}{|l|l|}
\hline$q^{L *}$ & $(a-c)\left(8 b^{3}-4 b^{2} d-4 b d^{2}+d^{3}\right) /\left(4 b^{2}-d^{2}\right)\left(4 b^{2}-3 d^{2}\right)$ \\
\hline$q^{F *}$ & $(a-c)\left(4 b^{2}-2 b d-d^{2}\right) / 2 b\left(4 b^{2}-3 d^{2}\right)$ \\
\hline$\pi^{L *}$ & $(a-c)^{2}\left(2 b^{2}-d^{2}\right)\left(8 b^{3}-4 b^{2} d-4 b d^{2}+d^{3}\right)^{2} / 2 b\left(4 b^{2}-d^{2}\right)^{2}\left(4 b^{2}-3 d^{2}\right)^{2}$ \\
\hline$\pi^{F *}$ & $(a-c)^{2}\left(4 b^{2}-2 b d-d^{2}\right)^{2} / 4 b\left(4 b^{2}-3 d^{2}\right)^{2}$ \\
\hline$w^{L *}$ & $(a-c)^{2}\left(2 b^{2}-d^{2}\right)\left(8 b^{3}-4 b^{2} d-4 b d^{2}+d^{3}\right)^{2} / 2 b\left(4 b^{2}-d^{2}\right)^{2}\left(4 b^{2}-3 d^{2}\right)^{2}$ \\
\hline$w^{F *}$ & $(a-c)^{2}\left(4 b^{2}-2 b d-d^{2}\right)^{2} / 4 b\left(4 b^{2}-d^{2}\right)\left(4 b^{2}-3 d^{2}\right)$ \\
\hline
\end{tabular}




\section{References}

Amir, Rabah and Isabel Grilo, 1999, "Stackelberg vs. Cournot Equilibrium," Games and Economic Behavior 26, 1-21.

Arvan, Lanny, 1991, "Flexibility Versus Commitment in Strategic Trade Policy Under Uncertainty: A Model of Endogenous Policy Leadership," Journal of International Economics 31, 341355.

Balboa, Orlando I., “Three Essays in Strategic International Trade,” Ph.D. dissertation, Vanderbilt University, in progress.

Boyer, Marcel and Michel Moreaux, 1987, "Being a Leader or a Follower," International Journal of Industrial Organization 5, 175-192.

Brander, James A., 1995, "Strategic Trade Policy," in Handbook of International Economics, Volume 3, ed. by Gene M. Grossman and Kenneth Rogoff. Amsterdam: Elsevier, pp. 13951455.

Brander, James A., and Barbara J. Spencer, 1985, "Export Subsidies and International Market Share Rivalry," Journal of International Economics 18, 83-100.

Carmichael, C., 1987, "The Control of Export Credit Subsidies and its Welfare Consequences," Journal of International Economics 23, 1-19.

Daughety, Andrew F., 1985, "Reconsidering Cournot: The Cournot Equilibrium is Consistent," RAND Journal of Economics 16, 368-379.

Daughety, Andrew F. and Jennifer F. Reinganum, 1994, “Asymmetric Information Acquisition and Behavior in Role Choice Models: An Endogenously Generated Signaling Game," International Economic Review 35, 795-819.

Dixit, Avinash K., 1984, “International Trade Policy for Oligopolistic Industries,” Economic Journal Conference Papers 94, 1-16.

Dowrick, Steven, 1986, "Von Stackelberg and Cournot Duopoly: Choosing Roles," RAND Journal of Economics 17, 251-260.

Driskill, Robert A., and Steven McCafferty, 1989, "Dynamic Duopoly with Output Adjustment Costs in International Markets: Taking the Conjectures Out of Conjectural Variations," in Trade Policies for International Competitiveness, ed. by R.C. Feenstra. Chicago: University of Chicago Press.

Eaton, Jonathan, and Gene M. Grossman, 1986, “Optimal Trade and Industrial Policy Under 
Oligopoly,” Quarterly Journal of Economics 101, 383-406.

Fershtman, Chaim and Kenneth Judd, 1987, "Equilibrium Incentives in Oligopoly," American Economic Review 77, 927-940.

Gal-Or, Esther, 1985, "First Mover and Second Mover Advantages," International Economic Review 26, 649-653.

Gal-Or, E., 1987, "First Mover Disadvantages with Private Information," Review of Economic Studies 54, 279-292.

Gruenspecht, Howard K., 1988, "Export Subsidies for Differentiated Products," Journal of International Economics 24, 331-344.

Hamilton, Jonathan H. and Steven M. Slutsky, 1990, "Endogenous Timing in Duopoly Games: Stackelberg or Cournot Equilibria," Games and Economic Behavior 2, 29-46.

Harris, Richard, 1985, "Why Voluntary Export Restraints are 'Voluntary'," Canadian Journal of Economics 18, 799-809.

Hwang, H.S., and C.T. Schulman, 1993," Strategic Non-intervention and the Choice of Trade Policy for International Oligopoly," Journal of International Economics 34, 73-93.

Klemperer, Paul and Margaret Meyer, 1986, "Price Competition vs. Quantity Competition: The Role of Uncertainty" RAND Journal of Economics 17, 618-638.

Krishna, Kala, 1989, "Trade Restrictions as Facilitating Practices,” Journal of International Economics 26, 251-270.

Lambertini, Luca, 2000, "Extended Games Played by Managerial Firms," Japanese Economic Review 51, 274-283.

Maggi, Giovanni, 1996a, “Endogenous Leadership in a New Market," RAND Journal of Economics 27, 641-659.

Maggi, Giovanni, 1996b, Strategic Trade Policies with Endogenous Mode of Competition," American Economic Review 86, 237-258.

Mailath, George J., 1993, "Endogenous Sequencing of Firm Decisions," Journal of Economic Theory 59, 169-182.

Makowski, Louis, 1987, “Are ‘Rational Conjectures' Rational?” Journal of Industrial Economics $36,35-47$. 
Miller, Nolan H. and Amit I. Pazgal, 2001, "The Equivalence of Price and Quantity Competition with Delegation," RAND Journal of Economics 32, 284-301.

Robson, Arthur J., 1990, "Duopoly with Endogenous Strategic Timing: Stackelberg Regained," International Economic Review 31, 263-274.

Sadanand, Venkatraman, 1988, "Endogenously Determined Price-Setting Monopoly in an Exchange Economy," Journal of Economic Theory 46, 172-178.

Sadanand, Asha and Venkatraman Sadanand, 1996, "Firm Scale and the Endogenous Timing of Entry: A Choice Between Commitment and Flexibility," Journal of Economic Theory 70, 516-30.

Singh, Nirvikar and Xavier Vives, 1984, "Price and Quantity Competition in a Differentiated Duopoly," RAND Journal of Economics 15, 546-554.

Sklivas, Steven D., 1987, "The Strategic Choice of Managerial Incentives," RAND Journal of Economics 18, 452-458.

van Damme, Eric and Sjaak Hurkens, 1999, "Endogenous Stackelberg Leadership," Games and Economic Behavior 28, 105-29.

Vickers, John, 1984, "Delegation and the Theory of the Firm," Economic Journal Supplement 95, 138-147. 